\title{
Penerapan Daily Physical Activity di Sekolah Malacampa Elementary School-Main, Tarlac City, Philippines
}

\author{
Nissa Aulia Belistiana Utami ${ }^{{ }^{*}}$, Andi Suntoda Situmorang ${ }^{1}$, Suherman Slamet ${ }^{1}$ \\ ${ }^{1}$ Universitas Pendidikan Indonesia, Indonesia
}

\section{Info Artikel}

Sejarah Artikel:

Diterima April 2020

Disetujui April 2020

Dipublikasikan Mei 2020

Keywords:

Daily Physical Activity, Elementary School.

\section{Abstrak}

Sistem Pendidikan di Filipina berubah karena merujuk program PBB yaitu Sustainable Development Goals. Salah satu perubahannya yaitu setiap siswa wajib mengikuti program Daily Physical Activity sebelum memulai pembelajaran. Penelitian ini merupakan penelitian yang dilakukan di Malacampa Elementary School-Main, Tarlac City, Philippines. Tujuan dari penelitian ini yaitu untuk mengetahui dampak apa saja yang terjadi setelah diterapkannya Daily Physical Activity yang dilakukan setiap pagi hari dalam jangka waktu yang panjang. Daily Physical Activity yang dilakukan adalah menari 10 sampai 15 menit. Jenis penelitian ini merupakan penelitian ex-post facto di mana peneliti meneliti program yang sedang terjadi di Filipina. Peneliti mengambil sampel satu kelas, yaitu kelas 6 SSES yang berjumlah 27 siswa. Berdasarkan hasil penelitian ini yaitu adanya dampak positif berupa anak lebih antusias dalam melakukan tugas gerak di kesehariannya dan negatif berupa siswa merasa bosan dengan lagu dan gerakan yang kurang bervariatif.

\begin{abstract}
The education system in the Philippines has changed because it refers to the United Nations program, the Sustainable Development Goals. One of the changes is that each student is required to attend the Daily Physical Activity program before starting learning. This research is conducted at Malacampa Elementary School-Main, Tarlac City, Philippines. The purpose of this study is to determine what impacts occur after the implementation of the Daily Physical Activity which is carried out every morning in the long run. Daily Physical Activity is done by dancing 10 to 15 minutes. This type of research is an ex-post-facto study in which the researcher examines a program that is happening in the Philippines. Researchers take samples of one class, named class 6 SSES, amounting to 27 students. Based on the results of this study, there are positive impacts in the form of children being more enthusiastic in doing daily tasks and negative in the form of students feeling bored with less varied songs and movements.
\end{abstract}




\section{PENDAHULUAN}

Pendidikan Jasmani merupakan bagian dari pendidikan keseluruhan yang mengutamakan aktivitas jasmani dan pembinaan hidup sehat untuk pertumbuhan dan perkembangan jasmani, mental, sosial dan emosional yang serasi, selaras, dan seimbang. Masalah yang dihadapi saat ini antara lain: sarana dan prasarana penjas yang terbatas, kurangnya jam pelajaran, perbandingan guru dan murid yang tidak sesuai. Dalam jurnalnya Widodo (2013) mengatakan bahwa peran pendidikan jasmani tentu sangatlah penting, dengan aktivitas jasmani dapat membuat manusia lebih ceria, rileks, tenang dan terbebas dari stress. Secara sosial, aktivitas jasmani dapat menjadi salah satu cara untuk mengenal dunia lebih jauh seperti bersosialisai dengan teman sebaya. Dengan demikian, aktivitas jasmani dapat bermanfaat bagi mental dan juga sosial (Widodo, 2014). Meskipun sudah diketahui oleh banyak orang tentang pentingnya aktivitas jasmani, namun masih banyak anak yang kurang bergerak. Widodo (2013) mengatakan bahwa ada 50 persen lebih anak sekolah dasar dalam kategori kurang aktif. Lebih tepatnya sebanyak 9,6 persen tidak aktif dan 54,1 persen kurang aktif. Berdasarkan survey yang dilakukan oleh Pusat Pengembangan Kualitas Jasmani Kemendiknas pada tahun 2003 masih ada 44,8\% siswa yang memiliki kebugaran dengan kategori kurang dan 7,9\% kategori kurang sekali (Widodo, 2004). Data ini membuktikan rendahnya tingkat kebugaran siswa. Rendahnya aktivitas fisik akan sangat rentan terhadap kesehatan mental yang tidak begitu baik (Biddle, 2011).

Peningkatan kualitas pendidikan olahraga dan kesehatan berbanding lurus dengan pencapaian Index Pembangunan Manusia (Diana, Yuliana, \& Yasmin, 2013). Oleh karena itu, berbagai masalah kesehatan terkait rendahnya aktivitas fisik memerlukan perhatian serius dari kalangan pendidikan di sekolah. Salah satu masalah yang dihadapi pada saat ini adalah kegemukan atau obesitas. Hal ini sesuai dengan yang ditemukan oleh Petosa dan kawan - kawannya, bahwa semakin meluasnya epidemi obesitas antara lain karena pola makan yang tidak teratur dan kian terbatasnya kesem- patan anak-anak dan remaja untuk melakukan aktivitas jasmani (Petosa, dkk. 2005).

Obesitas adalah suatu keadaan yang melebihi dari berat badan relatif seseorang, sebagai akibat penumpukan zat gizi terutama karbohidrat, protein dan lemak. Kondisi tersebut disebabkan oleh ketidakseimbangan antara konsumsi energi dan kebutuhan energi, yaitu konsumsi makanan (yang terlalu banyak) dibandingkan dengan kebutuhan atau pemakaian energi (yang lebih sedikit). Di Indonesia sudah banyak kasus tentang Obesitas, terutama di kalangan anak-anak. Hal ini terjadi karena faktor-faktor seperti peningkatan konsumsi makanan cepat saji (fast food), rendahnya aktivitas fisik, faktor genetik, pengaruh iklan, faktor psikologis, status sosial ekonomi, program diet, usia, dan jenis kelamin (Weni et al., 2015). Hasil Riskesdas tahun 2010 (Litbangkes, 2010) menunjukkan bahwa $21.7 \%$ orang dewasa Indonesia mengalami kegemukan (termasuk obesitas), dan perempuan memiliki prevalensi yang lebih tinggi (26.9\%) dibandingkan laki-laki (16.3\%) (Litbangkes, 2010). Salah satu cara penurunkan tingkatan obesitas tersebut yaitu dengan melakukan aktivitas fisik melalui pendidikan jasmani.

Selain dengan aktivitas fisik, pola hidup sehatpun perlu menjadi suatu acuan untuk mengurangi tingkat obesitas. Pola hidup sehat mempunyai peranan yang penting untuk meningkatkan dan mempertahankan kebugaran jasmani seseorang. Faktor-faktor yang mempengaruhi kesehatan di dalam pola hidup sehat adalah makanan dan olahraga. Di samping makanan dan olahraga yang dapat mempengaruhi kesehatan adalah gaya hidup seseorang, misalnya suka merokok, minum minuman keras, dll. Untuk mendapatkan kebugaran jasmani yang baik perlu memahami pola hidup sehat, yaitu: (1) Makan yang cukup, baik kualitas maupun kuantitas, (2) Istirahat, supaya tubuh memiliki waktu untuk recovery (pemulihan), sehingga dapat melakukan aktivitas dengan nyaman, dan (3) Berolahraga, yaitu salah satu alternatif yang paling efektif untuk memperoleh kebugaran, sebab berolahraga bermanfaat untuk fisik, psikis, maupun sosial. Di samping itu untuk meningkatkan dan mempertahankan kebugaran jasmani perlu menghindari 
gaya hidup yang kurang baik, supaya tidak mempengaruhi kesehatan, sehingga tubuh selalu dalam keadaan sehat dan bugar. Agar pola hidup sehat menjadi suatu kebiasaan, maka pola hidup sehat harus diajarkan dari usia dini. Dimulai dari hal kecil seperti mencuci tangan sebelum dan sesudah makan dan menggosok gigi sebelum tidur.

Mengapa pembiasaan gaya hidup aktif harus dimulai sejak dini? Karena, kebiasaan yang dilakukan sejak kecil cenderung menetap dan terbawa hingga dewasa dan juga semakin tinggi derajat kebugaraan seseorang maka semakin besar juga kemampuan fisik dan produktivitasnya (Sulistiyono, 2014). Aktivitas fisik memerlukan keterampilan motorik yang cukup agar anak mau terlibat dalam sebuah aktivitas fisik berupa permainan maupun olahraga. Hal ini tentu sulit untuk dicapai, manakala anak memiliki keterampilan gerak motorik yang rendah. Keterampilan motorik kasar sebagai sebuah prediktor penting pada partisipasi dalam aktivitas fisik selama masa remaja dan dewasa (Barnett, van Beurden, Morgan, Brooks, \& Beard, 2009; Veldman, S., Okely, A., Jones, R, 2015).

Pada tahun 2015 berbagai Negara di dunia sepakat membentuk komunitas global terkait program jangka panjang yang dinamakan Sustainable Development Goals (Tujuan Pembangunan Berkelanjutan). Terdapat 17 tujuan dengan 169 capaian yang terukur dan tenggat yang telah ditentukan oleh PBB sebagai agenda dunia pembangunan untuk kemaslahatan manusia dan planet bumi menurut United Nations (Lu, et al, 2015). Tujuan Pembangunan Berkelanjutan terkait dengan pendidikan secara khusus diarahkan untuk pengembangan pendidikan dan bertujuan untuk memastikan pendidikan yang inklusif dan berkualitas yang setara dan juga mendukung kesempatan belajar seumur hidup bagi semua. Hal tersebut juga menjadi tujuan utama berubahnya kurikulum di Filipina menjadi K-12, yang menegaskan untuk lebih mengutamakan aktivitas fisik sehari-hari di sekolah dasar dan tidak hanya berupa olahraga yang bersifat kecabangan. Dalam kurikulum tersebut juga menegaskan bahwa sebelum pembelajaran dimulai, semua sekolah dasar wajib melakukan Daily Physical
Activity. Salah satu program The Walking School Bus, yaitu program yang mengajak siswanya untuk berjalan kaki ke sekolah dan dijemput oleh guru atau orang dewasa lainnya seperti orang tua siswa. Namun, program tersebut harus berakhir karena adanya perubahan birokrasi di Kementrian dan Kebudayaan. Sehingga peneliti menyarankan untk melanjutkan peneltian tersebut untuk meningkatkan kebugaran jasmani di kalangan anak - anak (Widodo, 2014).

Berdasarkan uraian di atas, penulis akan menganalisis dampak dari penerapan Daily Physical Activity di Sekolah, berdasarkan pengalaman di Malacampa Elementary SchoolMain, Tarlac City, Phillipines.

\section{METODE}

Jenis penelitian ini merupakan penelitian ex-post facto karena penelitian ini sudah terjadi dan peneliti menganalisis tentang penerapan Daily Physical Activity yang dilakukan di Malacampa Elementary SchoolMain, Tarlac City, Philippines. Dan juga penelitian ini menggunakan metode penelitian kualitati. Penelitian ini dilakukan di Malacampa Elementary School-Main, Kota Tarlac, Filipina selama satu tahun ajaran akademik. Melibatkan 27 siswa kelas 6 SSES sekolah dasar dan juga dibantu dengan satu orang guru pamong.

Sesuai dengan kurikulum yang berlaku di Filipina, yaitu kurikulum K-12 yang mengharuskan siswa sekolah dasar belajar dari jam 7 pagi hingga jam 3.30 sore. Dan setiap pagi hari semua siswa beserta gurunya wajib melakukan upacara bendera dengan menggunakan pakaian tradisional Filipina. Dan hal tersebut tentu diterapkan juga di Malacampa Elementary School -Main, Tarlac City, Philippines. Setelah itu dilanjut dengan melakukan Daily Physical Activity yang berupa menari yang dilakukan selama 10 menit. Daily Physical Activity yaitu aktivitas fisik yang dilakukan secara rutin guna mengurangi dan mencegah penyakit kronis dengan diet sehat dan tidak merokok (WHO, 2003).

Setiap pagi siswa dibariskan sesuai ke- 
las masing-masing di lapangan upacara dengan rapih, setelah semua sudah berbaris, seorang guru memutar musik lalu dengan spontan seluruh siswa melakukan tarian yang diiringi lagu. Setelah melakukan aktivitas tersebut siswa kembali ke kelas masing - masing untuk melanjutkan aktivitas pembelajaran.

\section{HASIL DAN PEMBAHASAN}

Setelah diterapkannya program Daily Physical Activity di Malacampa Elementary School-Main, terlihat jelas dampak yang terjadi terhadap siswa di Malacampa Elementary School-Main. Yaitu antusias siswa meningkat dalam melakukan aktivitas gerak. Bukan hanya sekedar gerak dalam pembelajaran pendidikan jasmani, namun dalam melakukan aktivitas gerak di kehidupan sehari-hari. Hal tersebut terlihat dengan kegiatan yang dilakukan setiap siswa di Malacampa Elementary School-Main khususnya kelas 6 SSES dalam kegiatan sehariharinya. Hampir seluruh siswa lebih semangat dan antusias dalam melakukan pembelajaran yang bermemiliki tugas gerak, contohnya ketika pembelajaran sastra filipin, siswa ditugaskan untuk menceritakan kembali di depan kelas cerita yang sudah gurunya sampaikan dengan cara sekreatif mungkin. Lalu ada beberapa siswa yang menampilkan drama yang mengharuskan siswanya melakukan tugas gerak seperti saling menggendong untuk menjadi pohon yang menjadi rumah monyet. Selain itu, siswa-siswi di Malacampa Elementary School-Main setiap harinya sangat semangat untuk membantu membersihkan lingkungan sekolah. Di Malacampa Elementary School-Main tidak ada istilah kelompok piket untuk membersihkan kelas, melainkan sudah menjadi kewajiban seluruh siswa untuk membersihkannya kembali setelah dipakai, hal tersebut termasuk kedalam melakukan tugas gerak juga. Dan yang terakhir, ekstrakulikuler di Malacampa Elementary School-Main memiliki banyak peminat. Hal tersebut tentunya sangat bagus, karena dengan melakukan aktivitas gerak tersebut bisa mengurangi risiko penyakit obesitas dan juga. hipokinetik di kalangan anak - anak. Dampak setelah diterapkannya Daily Physical Activity selain peningkatan antusiasme dalam melakukan tugas gerak yaitu kebugaran dan kesehatan yang sta- bil. Hal tersebut terlihat dalam absensi siswa yang jarang sekali tidak masuk karena sakit. Namun, selain dampak positif, tentunya ada dampak negatif dalam penerapan Daily Physical Activity di Malacampa Elementary SchoolMain, yaitu siswa bosan dengan lagu pengiring tarian, karena lagu tersebut diganti setiap pergantian tahun pelajaran saja. Bisa dikatakan bahwa siswa akan terus mendengarkan lagu tersebut setiap hari dalam satu tahun.

\section{KESIMPULAN}

Daily Physical Activity di Malacampa Elementary School-Main, Tarlac City, Philippines sangat efektif untuk meningkatkan kebugaran siswa terutama siswa sekolah dasar. Dengan diterapkannya program tersebut sejak dini, maka hal tersebut akan menjadi sebuah kebiasaan yang bagus untuk siswa tersebut ketika dewasa nanti. Dengan penerapan program ini juga dapat membantu program jangka panjang yang dibuat oleh beberapa negara yaitu Sustainable Development Goals (SDGs) atau tujuan pembangunan berkelanjutan dalam poin ke empat yaitu Pendidikan Bermutu dan juga poin ke tiga yaitu Kesehatan yang Baik dan juga Kesejahteraan. Jika penerapan Daily Physical Activity dilakukan secara rutin dan dalam tempo yang panjang, maka dapat terlihat jelas peningkatan kebugaran jasmani ketika dewasa hal teresebut terlihat juga dalam hasil penelitian ini. Maka untuk penelitian yang akan datang, peneliti menyarankan agar menerapkan Daily Physical Activity di Indonesia, terutama di sekolah dasar. Selain itu, peneliti juga mengharapkan adanya penelitian yang menggunakan sistem pre-test dan post-test untuk memberikan hasil yang konkret dalam meneliti tingkat kebugaran siswa. Tentunya saran dari peneliti tersebut tidak akan bisa dilaksanakan dengan lancar jika tidak didukung oleh pemerintah, sekolah, guru dan siswa di Indonesia.

Penelitian yang disarankan oleh peneliti sangat penting untuk dilakukan karena untuk meningkatkan kualitas hidup aktif dan sehat, dan juga guna mendukung program Sustainable Development Goals diciptakan bukan hanya untuk negara Filipina saja, melainkan juga untuk Indonesia dan negara-negara lainnya. Maka dari itu, peneliti berikutnya dapat mengadopsi 
program yang sudah berjalan lancar di Filipina yaitu Daily Physical Activity berupa menari sebelum proses belajar dan mengajar dimulai.

\section{DAFTAR PUSTAKA}

Barnett, L. M., Van Beurden, E., Morgan, P. J., Brooks, L. O., \& Beard, J. R. (2009). Childhood motor skill proficiency as a predictor of adolescent physical activity. Journal of adolescent health, 44(3), 252-259.

Biddle, S. J., \& Asare, M. (2011). Physical activity and mental health in children and adolescents: a review of reviews. British journal of sports medicine, 45(11), 886895.

Diana, R., Yuliana, I., \& Yasmin, G. (2013). Faktor risiko kegemukan pada wanita dewasa indonesia. Jurnal Gizi Dan Pangan, 8(1), 1-8.

Litbangkes, B., \& Depkes, R. I. (2010). Riset Kesehatan Dasar: Riskesdas 2010. Badan Litbangkes, Kementerian Kesehatan. Jakarta.

Lu, Y., Nakicenovic, N., Visbeck, M., \& Stevance, A. S. (2015). Policy: five priorities for the UN sustainable development goals. Nature, 520(7548), 432-433.

Petosa RL, Hortz BV, Cardina CE, Suminski RR. 2005. Social Cognitive Theory Variables Associated with Physical Activity Among High School Students. International Journal of Sports Medicine, 26, 158-163.

Sulistiono, A. A. (2014). Kebugaran jasmani siswa pendidikan dasar dan menengah di Jawa Barat. Jurnal Pendidikan dan Kebudayaan, 20(2), 223-233.

Veldman, S., Okely, A., Jones, R. (2015). Promoting Gross Motor Skills in Toddlers: The Active Beginnings Pilot Cluster Randomized Trial. Perceptual \& Motor Skills Physical Development \& Measurement 2015, (C) Perceptual Motor Skills. $121, \quad 3, \quad 857-872 . \quad \mathrm{https}: / /$ doi.org/10.2466/10.PMS.121c27x5.
Weni, K. I. K., Isti, S., Nurul Huda, S., Listiana Purnaning, S., Mahardika Marta, A., Diana, M., \& Sholihah. (2015). Faktorfaktor yang mempengaruhi kejadian obesitas pada remaja. Jurnal Gizi Klinik Indonesia, 11(4), 179-190. https:// doi.org/10.22146/ijen.22900.

Widodo. (2004). Kualitas Jasmani Pelajar, Makalah: Seminar Ilmiah Hasil Penelitian Pusat Pengembangan Kualitas Jasmani, pada tanggal 4-5 Mei 2004 di Puncak, Bogor.

Widodo. (2012). Buku Pengantar Menjadi Guru Penjasorkes Teladan, Yogyakarta: Elmatera Publishing.

Widodo. (2013). Penerapan "7 Langkah Menyusun Rencana Disiplin Kelas Proaktif" karya Colvin dalam Pembudayaan Hidup Aktif dan Sehat di Sekolah, Jurnal Pendidikan \& Kebudayaan Volume 19 (3), 331-343

Widodo. (2014). Strategi Peningkatan Aktivitas Jasmani Siswa Sekolah Dasar di Luar Pembelajaran Pendidikan Jasmani, Olahraga dan Kesehatan di Indonesia. Jurnal Pendidikan Dan Kebudayaan, Vol. 20, Nomor 2, 20(2), 281-294.

World Health Organization. (2003). Guidelines for safe recreational water environments: Coastal and fresh waters (Vol. 1). World Health Organization. 